\title{
AMP010014A09 in Sus Scrofa Encodes an Analog of G Protein-Coupled Receptor 109A, Which Mediates the Anti-Inflammatory Effects of Beta- Hydroxybutyric Acid
}

\author{
Guangxin Chen Shoupeng Fu Wenqian Feng Bingxu Huang Shiyao Xu \\ Wei Wang Juxiong Liu \\ College of Veterinary Medicine, Jilin University, Changchun, China
}

\section{Key Words}

$\mathrm{AMP}+\cdot$ GPCRs $・ \mathrm{IPEC}-J 2 \cdot$ Monocytes $\bullet \mathrm{ST} \cdot$ Swine

\begin{abstract}
Background: Hydroxy-carboxylic acid receptor $2\left(\mathrm{HCA}_{2}\right.$ also called GPR109A) belongs to the G protein-coupled receptor (GPCR) family and is found in humans, rats, mice, hamsters and guinea pigs, but there are almost no reports of this protein in other species. In this investigation, we speculated that AMP010014A09 (AMP+) is a homologue of GPR109A in swine. Methods: To test this hypothesis, the following experiments were designed: monocytes isolated from the peripheral blood of swine were treated with LPS after pretreating with or without $\beta$-hydroxybutyric acid (BHBA), and the levels of pro-inflammatory cytokines and inflammatory proteins were assessed. CAMP levels induced by Forskolin in swine testicular (ST) and IPEC-J2 cells were detected with or without BHBA treatment and following silencing or stable transfection of the AMP+ gene. Results: AMP+ in swine exhibited a high level of homology with HM74A in humans and PUMA-G in mice. BHBA inhibited the LPS-induced secretion of the pro-inflammatory cytokines TNF- $\alpha$, IL- 6 and IL-1 $\beta$ and the inflammatory protein COX-2 in monocytes of swine. BHBA suppressed the Forskolin-induced CAMP level increase in ST cells, but failed to inhibit the accumulation of cAMP after the AMP+ gene was silenced with shRNA by transfecting cells with the pGPU6-GFP-Neo-AMP+-sus-392 plasmid. BHBA had no effect on CAMP levels in IPEC-J2 cells, but significantly inhibited the increase in CAMP induced by Forskolin treatment following transfection of the AMP+ gene into IPEC-J2 cells by a lentivirus vector. Conclusion: Our results indicated that AMP+ encodes a G proteincoupled receptor in Sus scrofa that inhibits cAMP levels and mediates anti-inflammatory effects in swine monocytes.

G. Chen and S. Fu contributed equally to this work.

Wei Wang and Juxiong Liu

College of Veterinary Medicine, Jilin University, 5333 Xi'an Road, Changchun 130062 Guangxin (China)

E-Mail wang_wei99@jlu.edu.cn / juxiong@jlu.edu.cn
\end{abstract}

KARGER 


\section{Cellular Physiology Cell Physiol Biochem 2017;42:1420-1430 \\ \begin{tabular}{l|l} 
DOI: 10.1159/000479206 & and Biochemistry \\
Published online: July 17, 2017 & $\begin{array}{l}\text { 2017 The Author(s). Published by S. Karger AG, Basel } \\
\text { www.karger.com/cpb }\end{array}$
\end{tabular} \\ Chen et al.: AMP010014A09 Encodes an Analog of GPR109A Receptor in Sus Scrofa}

\section{Introduction}

GPR81, GPR109A and GPR109B form a subfamily of G-protein-coupled receptors (GPCRs) for nicotinic acid (niacin) [1-3], and the endogenous ligands of the members of this GPCR subfamily were identified following reports from three research groups demonstrating that GPR109A binds to niacin [4-6]. The ketone body 3-hydroxy-butyrate (BHBA) is reported to be the endogenous ligand of GPR109A [7] and lactate is the endogenous ligand of GPR81 $[8,9]$; GPR109B is activated by 3-hydroxylated beta-oxidation intermediates, particularly 3-hydroxy-octanoate [3]. Among the members of this GPCR subfamily, GPR109A has attracted much attention and has been the subject of a large number of studies. GPR109A is a Gi protein-coupled receptor found in humans, rats, mice, hamsters and guinea pigs, whereas there are almost no reports of this protein in other species [4-6, 10]. BHBA is derived from the reduction of acetoacetate in the liver in all species and from the oxidation of butyrate exclusively in the ruminal epithelium. Previous studies have indicated that certain concentrations of BHBA inhibit immune cell-induced inflammation and atherosclerosis by activating of GPR109A; however, high concentrations of BHBA induce cattle hepatocyte inflammatory injury through the NF- $\kappa B$ signaling pathway, which may be activated by oxidative stress [11]. GPR109A is expressed by adipocytes, monocytes, macrophages, dermal dendritic cells and vascular endothelial cells, but not lymphocytes [4-6, 12-16], and is also present in retinal pigmented and colonic epithelial cells, keratinocytes, microglia, and normal mammary tissue [17-20]. The function of GPR109A was first described in adipocyte lipolysis whereby GPR109A inhibits the activity of adenylate cyclase and subsequently decreases cAMP levels, resulting in reduced protein kinase A and hormone-sensitive lipase activity $[5,21,22]$.

Butyrate, which is produced by bowel microbial fermentation of dietary carbohydrates, fiber, proteins and peptides [23-25], functions as the energy source for epithelial cells [26] and also stimulates the growth of small intestinal epithelium [23]. Previous studies have demonstrated that butyrate or sodium butyrate decreases intestinal permeability and enhances the intestinal barrier [27-29]. Intestinal permeability is related to diarrhea, and Fang et al. and Huang et al. observed that sodium butyrate decreases the incidence of diarrhea in weaned piglets, though the mechanism remains unclear [30, 31].

First reported by Uenishi [32], the AMP010014A09 gene is expressed in the porcine thymus, spleen, uterus, lung, liver, ovary and peripheral blood mononuclear cells. As the AMP+ gene shows high homology with the GPR109A gene, we hypothesized that AMP+ encodes an analog of GPR109A in swine that is activated by butyrate, niacin and BHBA. Identification of the butyrate receptor in swine not only will assist efforts to elucidate the mechanism by which butyrate ameliorates intestinal inflammation, the results may provide a potential target for treating piglet diarrhea. Moreover, the findings may also serve as a model for studying the functions and applications of GPR109A.

\section{Materials and Methods}

\section{Materials}

BHBA ( $\beta$-Hydroxybutyric acid), LPS (lipopolysaccharide), isobutyl-1-methylxanthine (IBMX) and 4-(3-butoxy-4-methoxy-benzyl) imidazolidone were purchased from Sigma (St. Louis, MO). Forskolin was purchased from Beyotime Institute of Biotechnology (Jiangsu, China). RMPI Medium 1640 and DMEM-F12 (Dulbecco's modified Eagle's medium and Ham's F-12 Nutrient Mixture) were obtained from Gibco (Grand Island, NY, USA). FBS (fetal bovine serum) was purchased from Clark (Australia). Trizol was obtained from Invitrogen (Carlsbad, CA, USA). Ficoll-Paque PLUS was purchased from GE Healthcare (Piscataway, NJ, USA). A PrimeScript RT reagent kit with gDNA Eraser was purchased from Takara (Kyoto, Japan). 2X Taq Master Mix was purchased from Vazyme (Nanjing, China). SYBR Green QuantiTect RT-PCR Kit and X-tremeGENE HP DNA Transfection Reagent were obtained from Roche (South San Francisco, CA, USA). Polybrene was obtained from Sangon Biotech Co., Ltd. (Shanghai, China). The lentivirus and the pGPU6-GFP-Neo-AMP+sus-392 plasmid, which were used to specifically increase AMP+ expression in IPEC-J2 cells and decrease 


\section{Cellular Physiology Cell Physiol Biochem 2017;42:1420-1430

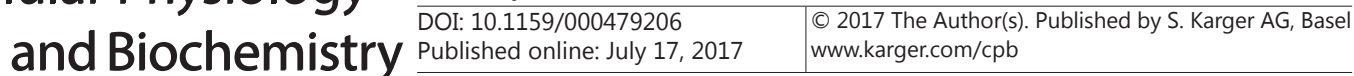 \\ Chen et al.: AMP010014A09 Encodes an Analog of GPR109A Receptor in Sus Scrofa}

AMP+ expression in ST cells, respectively, were synthesized by Sangon Biotech Co., Ltd. (Shanghai, China). All other reagents were of analytical grade or of the highest purity available.

\section{Animals}

Landraces used for the experiments were provided by the original breeding pig farm of Jilin University. All experimental animals were approved by the Jilin University Institutional Animal Care and Use Committee, and the experimental procedures were strictly performed according to the Guidelines for the Care and Use of Laboratory Animals in China. All pigs were provided with food and water ad libitum. Six to eight-week-old pigs were used for isolation of monocytes.

\section{Cell culture}

Monocytes were isolated from peripheral blood of landraces. Briefly, peripheral blood samples from swine were collected into heparinized collection tubes, diluted 1:2 with Hanks' balanced salt solution, overlaid onto Ficoll-Paque PLUS medium and centrifuged at $400 \times \mathrm{g}$ for $35 \mathrm{~min}$ at $20^{\circ} \mathrm{C}$. Next, peripheral blood mononuclear cells (PBMCs) were collected into a sterile centrifuge tube and washed twice with sterile Hanks' solution before centrifuging at $80 \times \mathrm{g}$ for $10 \mathrm{~min}$ at $20^{\circ} \mathrm{C}$. The supernatant was removed, and the PBMCs were with re-suspended in RMPI 1640 Medium supplemented with $10 \%$ (v/v) FBS and maintained at $37^{\circ} \mathrm{C}$ with $5 \% \mathrm{CO}_{2}$. After four hours, the PBMCs were washed twice using sterile Hanks' solution to remove non-adherent cells. The remaining cells were the monocytes used in experiments.

IPEC-J2, an intestinal epithelial cell line, was a kind gift from Dr. Guohua Wu (College of Animal Science and Technology, China Agricultural University). The swine testicular cell line (ST) isolated from swine fetal testes has been widely used in biomedical research related to pig virus infection. ST cells were purchased from ATCC. IPCE-J2 and ST cells were cultured in complete DMEM/F12 medium with 10\% (v/v) FBS. The cells were cultured in an incubator at $37^{\circ} \mathrm{C}$ in a humidified atmosphere of $5 \% \mathrm{CO}_{2}$.

Treatment of monocytes

LPS (Sigma-Aldrich, USA) was dissolved in phosphate-buffered saline (PBS) and used to induce monocyte secretion of pro-inflammatory cytokines and inflammatory protein. Monocytes were divided into the following four groups: the no treatment (NT) group, the BHBA (1.5 mM) treatment group, the LPS (1 $\mu \mathrm{g} / \mathrm{ml})$ treatment group, and the LPS $(1 \mu \mathrm{g} / \mathrm{ml})+$ BHBA $(1.5 \mathrm{mM})$ treatment group. The cells were cultured in serum-free RMPI 1640 for $3 \mathrm{~h}$ to reduce mitogenic effects and then pretreated with BHBA for $1 \mathrm{~h}$ before adding LPS. The monocytes were collected at $6 \mathrm{~h}$ and $12 \mathrm{~h}$ after stimulation to measure expression of the pro-inflammatory cytokines TNF- $\alpha$, IL-1- $\beta$ and IL- 6 and the inflammatory protein COX-2. Experiments for each of the different treatments were carried out in triplicate.

\section{Real-time quantitative PCR analysis}

Total RNA was extracted from cells using Trizol according to the supplier's protocol, and cDNA was synthesized using $2 \mu \mathrm{g}$ of total RNA. Briefly, $2 \mu \mathrm{l}$ of Oligo (dT)18 Primer and $2 \mu \mathrm{g}$ of total RNA were added to the reaction system, which adjusted to a volume of $14 \mu \mathrm{l}$ using diethyl pyrocarbonate (DEPC) water and mixed at $70^{\circ} \mathrm{C}$ for $5 \mathrm{~min}$. Next, $4 \mu \mathrm{l}$ X Reverse Transcriptase M-MLV Buffer, $0.5 \mu \mathrm{l}$ Reverse Transcriptase M-MLV, 1 $\mu \mathrm{d}$ dNTP mixture, and $0.5 \mu \mathrm{l}$ recombinant RNase inhibitor were added to the reaction system and incubated at $42^{\circ} \mathrm{C}$ for $90 \mathrm{~min}$ and then at $90^{\circ} \mathrm{C}$ for $5 \mathrm{~min}$. For PCR amplification, we diluted the cDNA 10 fold and then added $12.5 \mu \mathrm{l} 2 \mathrm{x}$ Taq Master Mix, $10.5 \mu \mathrm{l}$ cDNA, $1 \mu \mathrm{l}$ sense primer and $1 \mu \mathrm{l}$ antisense primer. Real-time quantitative RTPCR (qRT-PCR) was performed using a SYBR Green QuantiTect RT-PCR Kit with specific primers. The reaction was as follows: initial heating step at $94^{\circ} \mathrm{C}$ for $3 \mathrm{~min}$ followed by 40 cycles of two-step reactions at $94^{\circ} \mathrm{C}$ for $30 \mathrm{~s}$ and $60^{\circ} \mathrm{C}$ for $30 \mathrm{~s}$. The sequences of the primers used in this investigation are shown in Table 1.

Table 1. The primer sequences of TNF- $\alpha$, IL-1 $1 \beta$, IL-6, COX2, AMP+, and GAPDH

\begin{tabular}{|c|c|c|}
\hline Gene & Sequences & Length (bp) \\
\hline TNF- $\alpha$ & 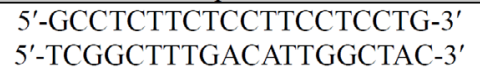 & 193 \\
\hline IL- $1 \beta$ & $\begin{array}{l}5^{\prime} \text {-ACCCAAAACCTGGACCTTG-3' } \\
5^{\prime} \text {-GGGATTCTTCATCGGCTTCT-3 }\end{array}$ & 132 \\
\hline IL-6 & $\begin{array}{c}\text { 5'-CTGGGTTCAATCAGGAGACC-3' } \\
\text { 5'-TTAGGGGTGGTGGCTTTGT-3' }\end{array}$ & 193 \\
\hline COX-2 & $\begin{array}{l}\text { 5'-CTCACACTCCTGAACACCTC-3 } \\
\text { 5'-TAAGCACATCGCACACTCTA-3 }\end{array}$ & 120 \\
\hline $\mathrm{AMP}+$ & $\begin{array}{l}\text { 5'-GTATGCTGGACCCTTTGGTG-3' } \\
\text { 5'-GCTGCGGTTATTGTTGGACT-3' }\end{array}$ & 119 \\
\hline GAPDH & $\begin{array}{l}5^{\prime} \text {-GCCATCACTGCCACCCAGAA-3' } \\
5^{\prime} \text {-GCCAGTGAGCTTCCCGTTGA-3' }\end{array}$ & 153 \\
\hline
\end{tabular}




\section{Cellular Physiology Cell Physiol Biochem 2017;42:1420-1430 \begin{tabular}{l|l} 
DOI: 10.1159/000479206 & O 2017 The Author(s). Published by S. Karger AG, Basel \\
www.karger.com/cpb
\end{tabular} \\ Chen et al.: AMP010014A09 Encodes an Analog of GPR109A Receptor in Sus Scrofa}

\section{RNA interference and stable transfection}

The plasmid pGPU6/GFP/Neo was used as the vector for transfecting AMP+, and the target site of AMP+ was AMP+-sus-392, with a target sequence of 5'-GCCGAATAATGCTCTTCATGT-3'. The sequence of the transcription product was 5'-GCCGAATAATGCTCTTCATGTTTCAAGAGAACATGAAGAGCATTATTCGGCTT-3'. Thus, the sequence of the recombinant plasmid was predicted. The pGPU6/GFP/Neo vector was used in the NC group. In this case, the target sequence was 5'-GTTCTCCGAACGTGTCACGT-3', and the sequence of the transcription product was 5'-GTTCTCCGAACGTGTCACGTTTCAAGAGAACGTGACACGTTCGGAGAATT-3'. Again, the sequence of the recombinant plasmid was as predicted. pGPU6-Neo containing the shRNA oligonucleotides were transfected into ST cells using X-tremeGENE HP DNA Transfection Reagent. The shRNA oligonucleotide most effectively silencing the AMP+ gene was chosen by assessing the degree to which AMP+ mRNA expression was decreased.

A stable transfection process, similar to described in a previous report [33], was used. Briefly, IPEC-J2 cells were seeded into a culture flask and incubated overnight. Next, $20 \mu \mathrm{l}$ of $1 \times 10^{8}-\mathrm{TU} / \mathrm{ml}$ lentivirus and 8 $\mu \mathrm{l}$ of polybrene were immediately added to the medium. The culture medium was replaced with complete medium after $24 \mathrm{~h}$, and the cells were observed $72-96 \mathrm{~h}$ later. The results of stable transfection were authenticated by observing cell fluorescence of cells (the lentivirus expresses green fluorescent protein) and AMP+ expression in the IPEC-J2 cell line.

\section{Immunofluorescence analyses}

A total of $5 \times 10^{4}$ cells were transferred onto glass slides pre-coated with rat tail tendon collagen type I and incubated overnight at $37^{\circ} \mathrm{C}$ with $5 \% \mathrm{CO}_{2}$. Next, we removed the complete culture medium, washed the slides 3 times with cold PBS, added $1 \mathrm{ml}$ immunol staining fix solution and incubated the slides at room temperature for $10 \mathrm{~min}$. The immunol staining fix solution was removed, and the slides were washed 3 times with cold PBS; $50 \mu \mathrm{l}$ PBS containing 5\% (v/v) donkey serum was added, and the slides were incubated for $3 \mathrm{~h}$ at room temperature. We diluted the anti-CD14 antibody with PBS containing 5\% (v/v) donkey serum, and added $50 \mu \mathrm{l}$ of the diluted antibody to the glass slides, which were incubated overnight at $4^{\circ} \mathrm{C}$. Next, the diluted primary antibody was removed by washing the slides 3 times with cold PBS, after which the fluorescein isothiocyanate (FITC)-conjugated secondary antibody diluted with PBS containing 5\% (v/v) donkey serum was applied, and the slides were incubated in the dark for $1 \mathrm{~h}$ at room temperature. The secondary antibody was removed by washing the slides 3 times with cold PBS, followed by application of $50 \mu \mathrm{l}$ DAPI and incubation at room temperature for $15 \mathrm{~min}$. DAPI was removed by washing the slides 3 times with cold PBS, and $20 \mu \mathrm{l}$ of antifade mounting medium was added; the slide then covered carefully with coverslips. Immunofluorescence microscopy analyses were performed using the requisite, dedicated software

\section{Intracellular cAMP of measurement}

A total of $2 \times 10^{5}$ cells/well were seeded into 96 -well plates and incubated at $37^{\circ} \mathrm{C}$ with $5 \% \mathrm{CO}_{2}$ for $12 \mathrm{~h}$. The complete medium was replaced with serum-free medium, and the cells were incubated at $37^{\circ} \mathrm{C}$ with $5 \% \mathrm{CO}_{2}$ for 3 to reduce mitogenic effects. Forskolin or BHBA was added to the induction buffer, which contained $1 \times$ PBS with $500 \mu \mathrm{M}$ IBMX and $100 \mu \mathrm{M}$ 4-(3-butoxy-4-methoxy-benzyl) imidazolidone; IBMX and 4-(3-butoxy-4-methoxy-benzyl) imidazolidone are broad-range phosphodiesterase inhibitors that inhibit cAMP hydrolysis. The cells were pretreated or not with forskolin $10 \mathrm{~min}$ before BHBA for $10 \mathrm{~min}$. After each of the treatments, cAMP levels were measured using the cAMP-Glo ${ }^{T M}$ assay according to the supplier's protocol. Experiments for each of the different treatments were carried out in triplicate.

\section{Statistics}

The results are expressed as means \pm SE. Data were analyzed using the statistical software package SPSS 12.0 (SPSS Inc., Chicago, IL, USA). Groups were compared by one-way analysis of variance (ANOVA) followed by the least significant difference test. ${ }^{*} P<0.05$ was considered significant, and ${ }^{* *} P<0.01$ was considered markedly significant. 


\section{Cellular Physiology and Biochemistry

\section{Results}

AMP+ has a high similarity with HM74A and PUMA-G

To identify AMP+ as an analog of GPR109A, we compared the nucleotide and amino acid sequences of AMP+ with those of HM74A and PUMA-G. AMP+ exhibits nucleotide homology, amino acid identity and amino acid similarity of $86.239 \%, 82.044 \%$ and $90.61 \%$ with HM74A. Furthermore, nucleotide homology, amino acid identity, and amino acid similarity between AMP+ and PUMA-G are $82.15 \%, 82.073 \%$ and $87.39 \%$ (Fig. $1 \mathrm{~A}$ and B). The structures of the three proteins were predicted using "SWISS-MODEL" (Fig. 1C-E), and the models showed

Fig. 1. AMP+ has high similarity with HM74A and PUMA-G. (A) The amounts of nucleotides and amino acids in AMP+, HM74A and PUMA-G. (B) Results of the comparisons between nucleotide and amino acid of AMP+, HM74A and PUMA-G. (C) Protein models of AMP+, HM74A and PUMA-G.
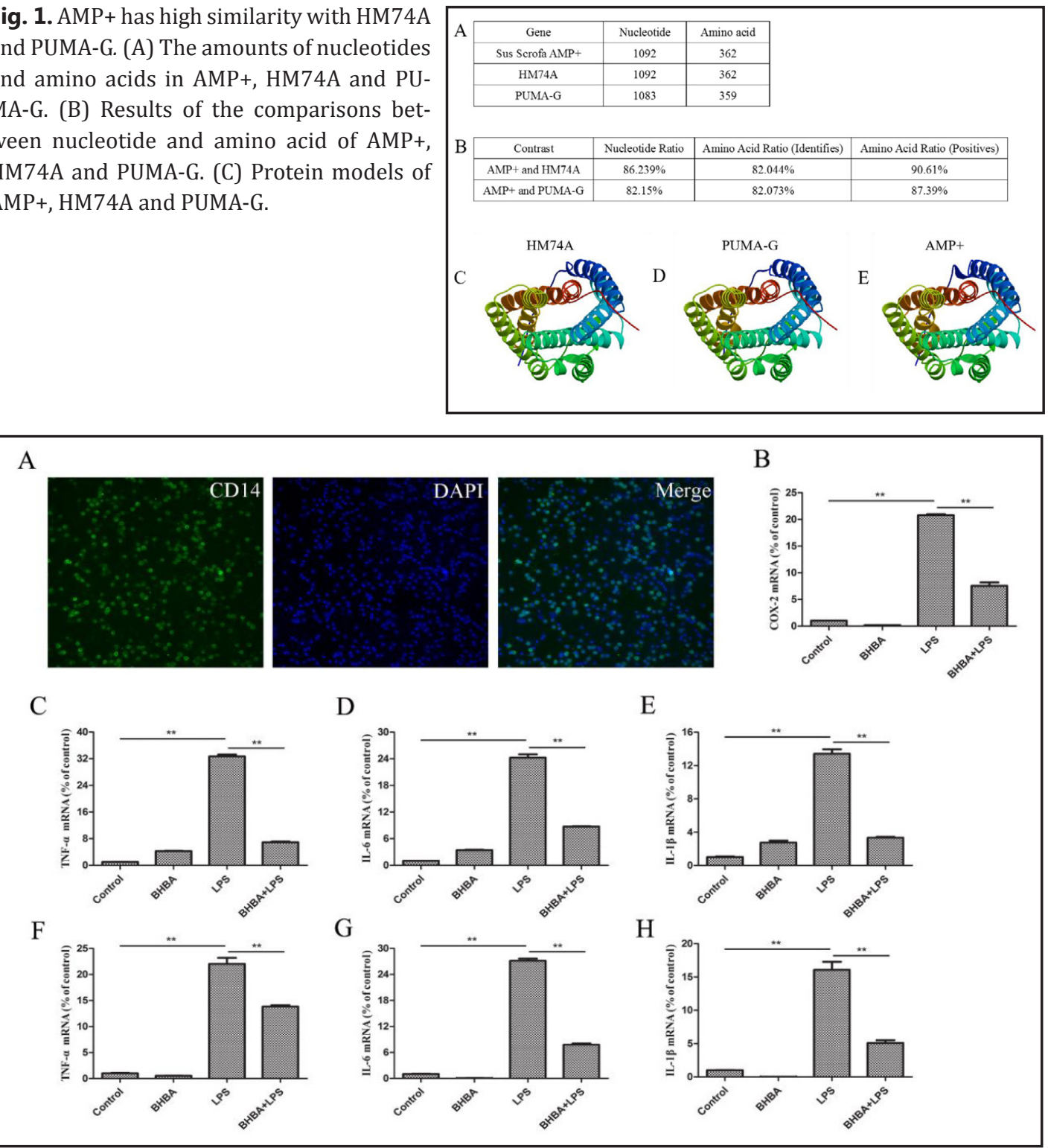

Fig. 2. BHBA inhibited LPS-induced increases in levels of pro-inflammatory cytokines and an inflammatory protein in monocytes. (A) Monocytes were identified using an anti-CD14 antibody (green) and DAPI staining (blue). Monocytes were cultured in serum-free RMPI 1640 medium for $3 \mathrm{~h}$ to reduce mitogenic effects, pretreated with or without BHBA $(1.5 \mathrm{mM})$ for $1 \mathrm{~h}$, and then treated with or without LPS $(1 \mu \mathrm{g} / \mathrm{ml})$ for 6 and 12 h. (B) Expression of COX-2, LPS treated for $4 \mathrm{~h}\left(\mathrm{n}=3,{ }^{*} P<0.05,{ }^{* *} P<0.01\right)$. (C), (D) and (E) Expression of TNF, IL-1 $\beta$ and IL- 6 respectively, LPS treated for $6 \mathrm{~h}\left(\mathrm{n}=3,{ }^{*} P<0.05\right.$, $\left.{ }^{* *} P<0.01\right)$. (F), (G) and (H) Expression of TNF, IL-1 $\beta$ and IL- 6 respectively, LPS treated for $12 \mathrm{~h}\left(\mathrm{n}=3,{ }^{*} P<0.05,{ }^{* *} P<0.01\right)$. 
A

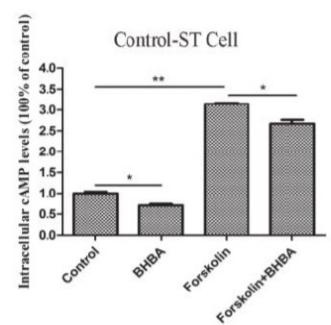

C

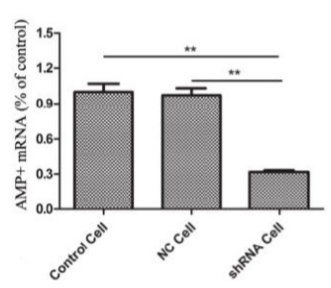

B
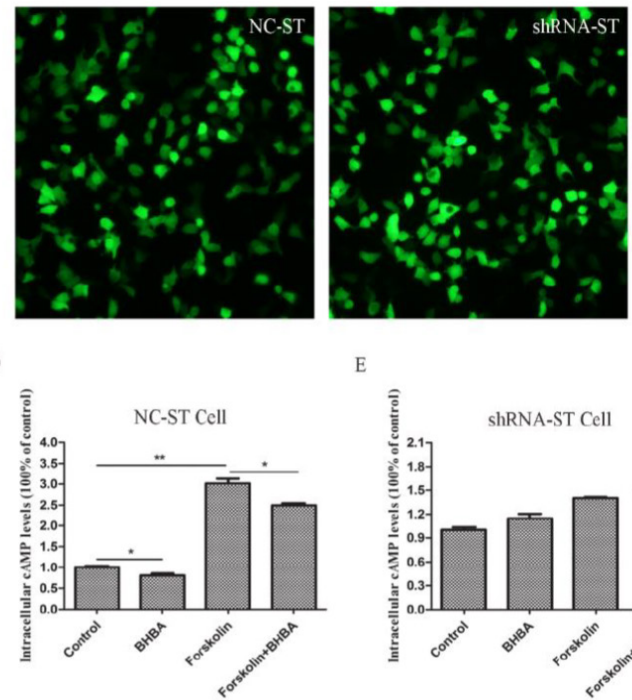

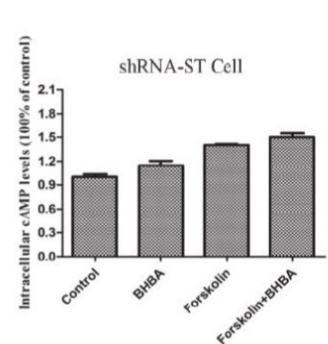

Fig. 3. Effect of BHBA on intracellular cAMP levels in ST cells. (A) Intracellular cAMP levels in control ST cells treated with or without forskolin and BHBA ( $\left.\mathrm{n}=3,{ }^{*} P<0.05,{ }^{* *} P<0.01\right)$. (B) Transfection results for NC and shRNA plasmid $(\mathrm{n}=3)$. The shRNA plasmid reduced AMP+ mRNA expression levels, and the NC plasmid failed to decrease AMP+ mRNA expression (C). (D, E) Intracellular cAMP levels in ST cells transfected with the NC and shRNA plasmids ( $\left.\mathrm{n}=3,{ }^{*} P<0.05,{ }^{* *} P<0.01\right)$.

very minor differences. All data indicated that AMP+ has high homology with HM74A and PUMA-G, despite originating from different species.

BHBA inhibited LPS-induced expression of pro-inflammatory cytokines and an inflammatory protein in monocytes

As demonstrated by immunofluorescence and DAPI stating, most of the cells isolated from swine peripheral blood were monocytes (Fig. 2A). LPS was utilized to induce inflammation in these cells, and BHBA significantly decreased the LPS-induced increase in levels of COX-2 expression (Fig. 2B). In cells pretreated with BHBA for $1 \mathrm{~h}$ and then treated with LPS for $6 \mathrm{~h}$, the expression levels of pro-inflammatory cytokines TNF- $\alpha$, IL-1 $\beta$, and IL- 6 were significantly decreased compared to those in the LPS group (Fig. 2C, D and E). Similar inhibition was observed with LPS treatment for $12 \mathrm{~h}$ after pretreating with BHBA for $1 \mathrm{~h}$. (Fig. 2F, G and H).

\section{Effects of BHBA on intracellular cAMP levels in ST cells}

GPR109A belongs to the Gi family of GPCRs and inhibits the activity of adenylate cyclase following activation by BHBA, which subsequently decreases cAMP levels. Therefore, we utilized BHBA to examine reductions in cAMP levels of ST cells silenced for AMP+. The results indicated that forskolin significantly increased cAMP synthesis and that BHBA significantly attenuated this forskolin-induced cAMP synthesis in ST cells (Fig. 3A). ST cells were transfected with pGPU6-GFP-Neo-AMP+-sus-392 and pGPU6-GFP-Neo-AMP+-sus-NC plasmids (Fig. 3B, C). In the control ST cells transfected with the NC plasmid, no significant change in cAMP levels was observed (Fig. 3D). BHBA failed to inhibit the synthesis of cAMP in ST cells transfected with plasmid containing AMP+ shRNA. (Fig. 3E).

Stable transfection of the AMP+ gene into IPEC-J2 cell

We had previously confirmed that several tissues of swine express AMP+, but that AMP+ was not expressed in the IPEC-J2 (NT) (Fig. 4A), we presumed that AMP+ was not 
Fig. 4. Stable transfection of the AMP+ gene into IPEC-J2 cells. (A) PCR results for IPEC-J2 (NT), NC-IPEC-J2 (NC) and AMP+IPEC-J2 (AMP+) cells. (B) Lentiviral transfection results for NC and AMP+. Green indicates positively transfected cells.
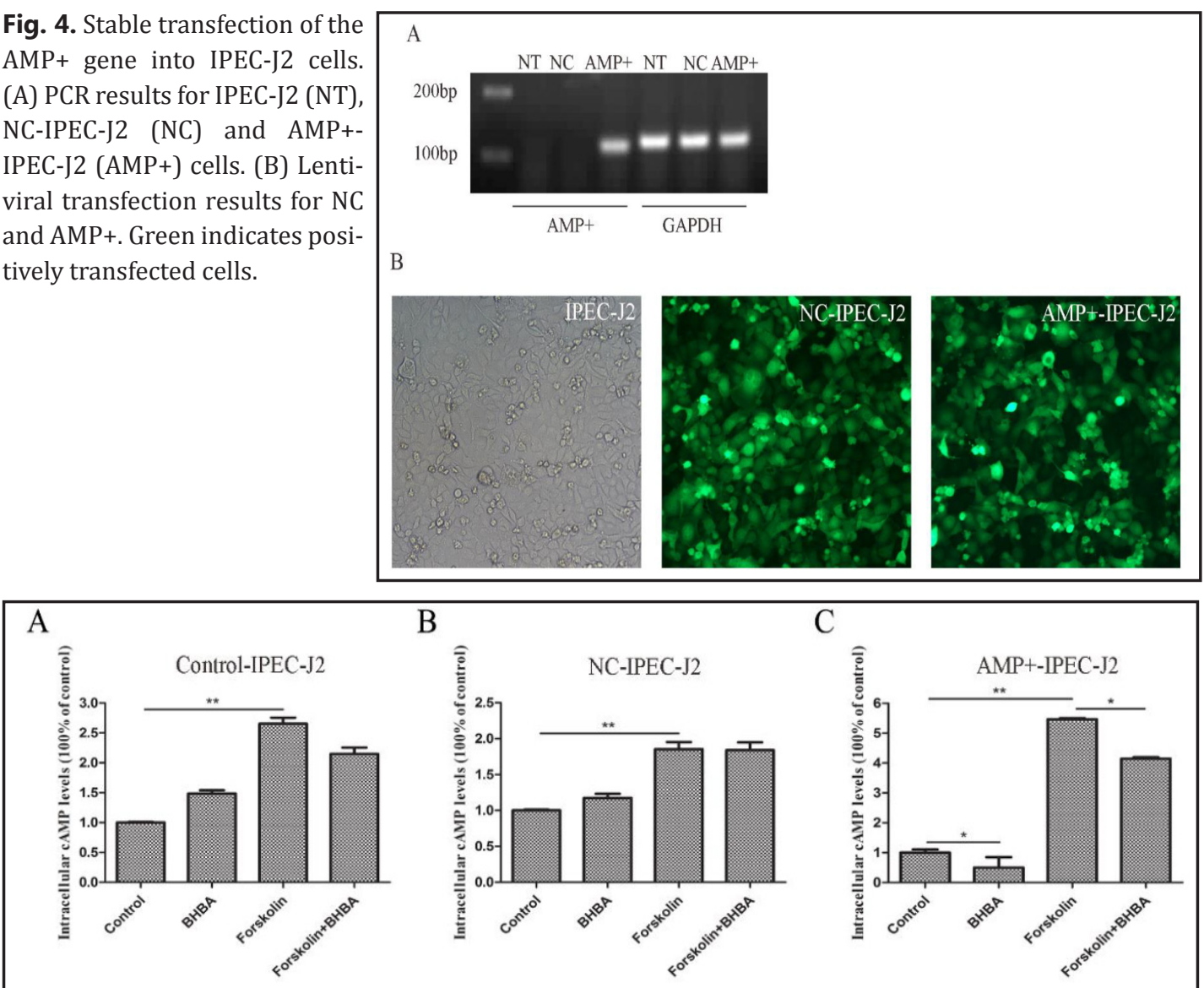

Fig. 5. Effects of BHBA on intracellular cAMP levels in IPEC-J2 cells. (A) Intracellular cAMP levels of IPCE-J2 cells treated with or without forskolin and BHBA $\left(n=3,{ }^{*} P<0.05,{ }^{*} P<0.01\right)$. (B) Intracellular cAMP levels of NC-IPCE-J2 cells treated with or without forskolin and BHBA ( $\left.\mathrm{n}=3,{ }^{*} P<0.05,{ }^{* *} P<0.01\right)$. (C) Intracellular cAMP levels of AMP+IPCE-J2 cells treated with or without forskolin and BHBA ( $\left.n=3,{ }^{*} P<0.05,{ }^{* *} P<0.01\right)$.

expressed in the IPEC-J2 cell line, we transfected AMP+ into IPEC-J2 cells using a lentivirus vector containing the gene. According to our results, IPEC-J2 (NT) and NC-IPEC-J2 cells did not express AMP+, whereas AMP+-IPEC-J2 cells did express AMP+ (Fig. 4A). The lentivirus produces green fluorescence protein, which facilitates observation of positively transfected cells by fluorescence microscopy (Fig. 4B). Microscopy and PCR indicated that we had successfully transfected AMP+ into IPEC-J2 cells and the transfection efficiency was very high.

cAMP levels were inhibited by BHBA in IPEC-J2 cells transfected with AMP+.

We treated IPEC-J2, NC-IPEC-J2 and AMP+-IPEC-J2 cells with BHBA and forskolin. Compared with the NT group, BHBA had no effect on cAMP levels in the control-IPEC-J2 cells, whereas forskolin increased intracellular cAMP levels (Fig. 5A). The same results were observed in NC-IPEC-J2 cells (Fig. 5B): BHBA significantly decreased cAMP levels in AMP+IPEC-J2 cells with or without forskolin treatment (Fig. 5C).

\section{Discussion}

LPS has been widely used to establish in vitro models of inflammation model [34, 35]. In this study, LPS was used to induce secretion of pro-inflammatory cytokines and an 


\section{Cellular Physiology Cell Physiol Biochem 2017;42:1420-1430

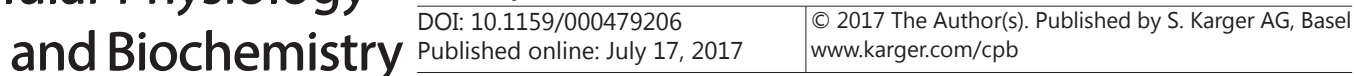 \\ Chen et al.: AMP010014A09 Encodes an Analog of GPR109A Receptor in Sus Scrofa}

inflammatory protein in monocytes. The results indicated that BHBA inhibited LPS-induced release of the pro-inflammatory cytokines TNF- $\alpha$, IL- $1 \beta$ and IL- 6 and the inflammatory protein COX-2. This is consistent with our previous results that BHBA suppresses the LPSinduced release of TNF- $\alpha$, IL-1 $\beta$ and IL- 6 via GPR109A in primary rat microglial cells and BV-2 cells [36, 37]. Similarly, niacin has been demonstrated to exert potent anti-inflammatory effects in human adipocytes and monocytes through GPR109A-dependent mechanisms [38, 39]. In addition, niacin and BHBA suppress the TNF- $\alpha$-induced release of pro-inflammatory cytokines by GPR109A in retinal pigment epithelial cells [18]. These studies highlight the role of GPR109A in anti-inflammation. Therefore, we hypothesized that GPR109A or its' analog is also present in swine monocytes.

Niacin rapidly reduced cAMP levels in human basal macrophages pre-incubated with or without pertussis toxin (PTX) for $18 \mathrm{~h}$; although cAMP levels were reduced in the niacin group, the effect was not observed in the PTX group [40]. Niacin also inhibited intracellular cAMP synthesis induced by forskolin in mouse primary hepatocytes [41]. These reports indicate that activation of GPR109A decreases cAMP levels, this consistent with our results that BHBA reduced the forskolin-induced increases in intracellular cAMP levels in ST cells. Our results also indicated that ST cells contain a receptor or analog that can be activated by BHBA, resulting in a subsequent decrease in intracellular cAMP levels. Moreover, silencing of the AMP+ gene with shRNA abolished the inhibitiory effect of BHBA on cAMP levels. Next, we observed that BHBA had no effects on the cAMP levels in IPEC-J2 cells, which do not express the AMP+ gene. However, when we transfected the AMP+ gene into these cells, BHBA decreased forskolin-induced increases in intracellular cAMP levels. Our results are similar to previous reports demonstrating that GPR109A is activated upon binding of niacin and functions in a G protein-coupled manner to decrease cAMP production in GPR109Aexpressing Chinese hamster ovary-K1 cells [5]. Niacin also inhibited forskolin-induced cAMP synthesis in GPR109A-expressing HEK-293 cells, but this suppression was abolished when the cells were pretreated with PTX $[42,43]$. Taken together, the results from previous studies and the current study led us to hypothesize that AMP+ is activated by BHBA, causing decreases in intracellular cAMP levels. The results also indicated that AMP+ is the GPR109A analog in swine and can be activated by BHBA.

Our findings not only reveal the potential mechanism of by which sodium butyrate ameliorates diarrhea in weaned piglets but also provide a powerful evidence for the presence of GPR109A in various species. Previous studies have indicated that niacin reduces inflammation in atherosclerosis [44], sepsis [45], obesity [46], diabetic retinopathy [18] and renal disease [47] via activation of GPR109A. Therefore, our study provides a model for investigating the functions and applications of GPR109A. For example, in vascular disease, niacin has been used as an antidyslipidemic drug to prevent and treat atherosclerosis, effects that are mediated by immune cell GPR109A [44, 48, 49]. Our findings in swine will may provide the basis for a more appropriate animal model for atherosclerosis than mouse models because swine is a larger mammal, compared to mice, has more physiological similarities to humans.

\section{Conclusion}

The results of our experiments provide strong evidence indicating that the AMP+ gene encodes a GPCR in swine that has high homology with GPR109A.

\section{Acknowledgements}

This work was funded by the National Nature Science Foundation of China (31572479, 31372396, 31672509, 31602020). 


\section{Cellular Physiology Cell Physiol Biochem 2017;42:1420-1430

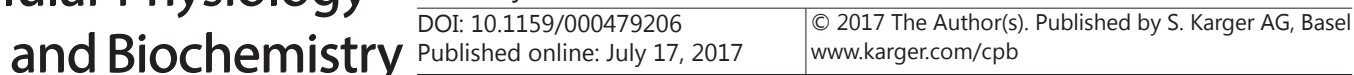 \\ Chen et al.: AMP010014A09 Encodes an Analog of GPR109A Receptor in Sus Scrofa}

\section{Disclosure Statement}

The authors declare no conflict of interest.

\section{References}

-1 Lee DK, Nguyen T, Lynch KR, Cheng R, Vanti WB, Arkhitko O, Lewis T, Evans JF, George SR, O'Dowd BF: Discovery and mapping of ten novel G protein-coupled receptor genes. Gene 2001;275:83-91.

-2 Nomura H, Nielsen BW, Matsushima K: Molecular cloning of cDNAs encoding a LD78 receptor and putative leukocyte chemotactic peptide receptors. Int Immunol 1993;5:1239-1249.

-3 Ahmed K, Tunaru S, Langhans CD, Hanson J, Michalski CW, Kolker S, Jones PM, Okun JG, Offermanns S: Deorphanization of GPR109B as a receptor for the beta-oxidation intermediate 3-OH-octanoic acid and its role in the regulation of lipolysis. J Biol Chem 2009;284:21928-21933.

4 Soga T, Kamohara M, Takasaki J, Matsumoto S, Saito T, Ohishi T, Hiyama H, Matsuo A, Matsushime $\mathrm{H}$, Furuichi K: Molecular identification of nicotinic acid receptor. Biochem Biophys Res Commun 2003;303:364-369.

5 Tunaru S, Kero J, Schaub A, Wufka C, Blaukat A, Pfeffer K, Offermanns S: PUMA-G and HM74 are receptors for nicotinic acid and mediate its anti-lipolytic effect. Nat Med 2003;9:352-355.

6 Wise A, Foord SM, Fraser NJ, Barnes AA, Elshourbagy N, Eilert M, Ignar DM, Murdock PR, Steplewski K, Green A, Brown AJ, Dowell SJ, Szekeres PG, Hassall DG, Marshall FH, Wilson S, Pike NB: Molecular identification of high and low affinity receptors for nicotinic acid. J Biol Chem 2003;278:9869-9874.

7 Taggart AK, Kero J, Gan X, Cai TQ Cheng K, Ippolito M, Ren N, Kaplan R, Wu K, Wu TJ, Jin L, Liaw C, Chen R, Richman J, Connolly D, Offermanns S, Wright SD, Waters MG: (D)-beta-Hydroxybutyrate inhibits adipocyte lipolysis via the nicotinic acid receptor PUMA-G. J Biol Chem 2005;280:26649-26652.

$>8$ Liu C, Wu J, Zhu J, Kuei C, Yu J, Shelton J, Sutton SW, Li X, Yun SJ, Mirzadegan T, Mazur C, Kamme F, Lovenberg TW: Lactate inhibits lipolysis in fat cells through activation of an orphan G-protein-coupled receptor, GPR81. J Biol Chem 2009;284:2811-2822.

-9 Cai TQ, Ren N, Jin L, Cheng K, Kash S, Chen R, Wright SD, Taggart AK, Waters MG: Role of GPR81 in lactatemediated reduction of adipose lipolysis. Biochem Biophys Res Commun 2008;377:987-991.

10 Torhan AS, Cheewatrakoolpong B, Kwee L, Greenfeder S: Cloning and characterization of the hamster and guinea pig nicotinic acid receptors. J Lipid Res 2007;48:2065-2071.

11 Shi X, Li X, Li D, Li Y, Song Y, Deng Q, Wang J, Zhang Y, Ding H, Yin L, Zhang Y, Wang Z, Li X, Liu G: beta-Hydroxybutyrate activates the NF-kappaB signaling pathway to promote the expression of proinflammatory factors in calf hepatocytes. Cell Physiol Biochem 2014;33:920-932.

12 Hanson J, Gille A, Zwykiel S, Lukasova M, Clausen BE, Ahmed K, Tunaru S, Wirth A, Offermanns S: Nicotinic acid- and monomethyl fumarate-induced flushing involves GPR109A expressed by keratinocytes and COX2-dependent prostanoid formation in mice. J Clin Invest 2010;120:2910-2919.

13 Maciejewski-Lenoir D, Richman JG, Hakak Y, Gaidarov I, Behan DP, Connolly DT: Langerhans cells release prostaglandin D2 in response to nicotinic acid. J Invest Dermatol 2006;126:2637-2646.

$>14$ Tang H, Lu JY, Zheng X, Yang Y, Reagan JD: The psoriasis drug monomethylfumarate is a potent nicotinic acid receptor agonist. Biochem Biophys Res Commun 2008;375:562-565.

15 Schaub A, Futterer A, Pfeffer K: PUMA-G, an IFN-gamma-inducible gene in macrophages is a novel member of the seven transmembrane spanning receptor superfamily. Eur J Immunol 2001;31:3714-3725.

16 Hughes-Large JM, Pang DK, Robson DL, Chan P, Toma J, Borradaile NM: Niacin receptor activation improves human microvascular endothelial cell angiogenic function during lipotoxicity. Atherosclerosis 2014;237:696-704.

17 Elangovan S, Pathania R, Ramachandran S, Ananth S, Padia RN, Lan L, Singh N, Martin PM, Hawthorn L, Prasad PD, Ganapathy V, Thangaraju M: The niacin/butyrate receptor GPR109A suppresses mammary tumorigenesis by inhibiting cell survival. Cancer Res 2014;74:1166-1178.

18 Gambhir D, Ananth S, Veeranan-Karmegam R, Elangovan S, Hester S, Jennings E, Offermanns S, Nussbaum JJ, Smith SB, Thangaraju M, Ganapathy V, Martin PM: GPR109A as an anti-inflammatory receptor in retinal pigment epithelial cells and its relevance to diabetic retinopathy. Invest Ophthalmol Vis Sci 2012;53:22082217. 


\section{Cellular Physiology Cell Physiol Biochem 2017;42:1420-1430 \begin{tabular}{l|l} 
DOI: 10.1159/000479206 & $\begin{array}{l}\text { O 2017 The Author(s). Published by S. Karger AG, Basel } \\
\text { www.karger.com/cpb }\end{array}$
\end{tabular} \\ Chen et al.: AMP010014A09 Encodes an Analog of GPR109A Receptor in Sus Scrofa}

19 Kostylina G, Simon D, Fey MF, Yousefi S, Simon HU: Neutrophil apoptosis mediated by nicotinic acid receptors (GPR109A). Cell Death Differ 2008;15:134-142.

20 Rahman M, Muhammad S, Khan MA, Chen H, Ridder DA, Muller-Fielitz H, Pokorna B, Vollbrandt T, Stolting I, Nadrowitz R, Okun JG, Offermanns S, Schwaninger M: The beta-hydroxybutyrate receptor HCA2 activates a neuroprotective subset of macrophages. Nat Commun 2014;5:3944.

21 Carlson LA, Oro L: The effect of nicotinic acid on the plasma free fatty acid; demonstration of a metabolic type of sympathicolysis. Acta Med Scand 1962;172:641-645.

-22 Carlson LA: Studies on the effect of nicotinic acid on catecholamine stimulated lipolysis in adipose tissue in vitro. Acta Med Scand 1963;173:719-722.

23 Guilloteau P, Martin L, Eeckhaut V, Ducatelle R, Zabielski R, Van Immerseel F: From the gut to the peripheral tissues: the multiple effects of butyrate. Nutr Res Rev 2010;23:366-384.

24 Leonel AJ, Alvarez-Leite JI: Butyrate: implications for intestinal function. Curr Opin Clin Nutr Metab Care 2012;15:474-479.

25 Macfarlane S, Macfarlane GT: Regulation of short-chain fatty acid production. Proc Nutr Soc 2003;62:67-72.

26 Chen J, Li Y, Tian Y, Huang C, Li D, Zhong Q, Ma X: Interaction between Microbes and Host Intestinal Health: Modulation by Dietary Nutrients and Gut-Brain-Endocrine-Immune Axis. Curr Protein Pept Sci 2015;16:592-603.

27 Wang HB, Wang PY, Wang X, Wan YL, Liu YC: Butyrate enhances intestinal epithelial barrier function via upregulation of tight junction protein Claudin-1 transcription. Dig Dis Sci 2012;57:3126-3135.

28 Peng L, Li ZR, Green RS, Holzman IR, Lin J: Butyrate enhances the intestinal barrier by facilitating tight junction assembly via activation of AMP-activated protein kinase in Caco-2 cell monolayers. J Nutr 2009;139:1619-1625.

29 Peng L, He Z, Chen W, Holzman IR, Lin J: Effects of butyrate on intestinal barrier function in a Caco-2 cell monolayer model of intestinal barrier. Pediatr Res 2007;61:37-41.

30 Fang CL, Sun H, Wu J, Niu HH, Feng J: Effects of sodium butyrate on growth performance, haematological and immunological characteristics of weanling piglets. J Anim Physiol Anim Nutr (Berl) 2014;98:680-685.

- 31 Huang C, Song P, Fan P, Hou C, Thacker P, Ma X: Dietary Sodium Butyrate Decreases Postweaning Diarrhea by Modulating Intestinal Permeability and Changing the Bacterial Communities in Weaned Piglets. J Nutr 2015;145:2774-2780.

32 Uenishi H, Eguchi T, Suzuki K, Sawazaki T, Toki D, Shinkai H, Okumura N, Hamasima N, Awata T: PEDE (Pig EST Data Explorer): construction of a database for ESTs derived from porcine full-length cDNA libraries. Nucleic Acids Res 2004;32:D484-488.

-33 Sun L, Zhao M, Zhang J, Lv M, Li Y, Yang X, Liu A, Wu Z: MiR-29b Downregulation Induces Phenotypic Modulation of Vascular Smooth Muscle Cells: Implication for Intracranial Aneurysm Formation and Progression to Rupture. Cell Physiol Biochem 2017;41:510-518.

-34 Halmer R, Davies L, Liu Y, Fassbender K, Walter S: The Innate Immune Receptor CD14 Mediates Lymphocyte Migration in EAE. Cell Physiol Biochem 2015;37:269-275.

-35 Song L, Kang C, Sun Y, Huang W, Liu W, Qian Z: Crocetin Inhibits Lipopolysaccharide-Induced Inflammatory Response in Human Umbilical Vein Endothelial Cells. Cell Physiol Biochem 2016;40:443-452.

-36 Fu SP, Li SN, Wang JF, Li Y, Xie SS, Xue WJ, Liu HM, Huang BX, Lv QK, Lei LC, Liu GW, Wang W, Liu JX: BHBA suppresses LPS-induced inflammation in BV-2 cells by inhibiting NF-kappaB activation. Mediators Inflamm 2014;2014:983401.

-37 Fu SP, Wang JF, Xue WJ, Liu HM, Liu BR, Zeng YL, Li SN, Huang BX, Lv QK, Wang W, Liu JX: Anti-inflammatory effects of BHBA in both in vivo and in vitro Parkinson's disease models are mediated by GPR109Adependent mechanisms. J Neuroinflammation 2015;12:9.

-38 Digby JE, Martinez F, Jefferson A, Ruparelia N, Chai J, Wamil M, Greaves DR, Choudhury RP: Antiinflammatory effects of nicotinic acid in human monocytes are mediated by GPR109A dependent mechanisms. Arterioscler Thromb Vasc Biol 2012;32:669-676.

-39 Digby JE, McNeill E, Dyar OJ, Lam V, Greaves DR, Choudhury RP: Anti-inflammatory effects of nicotinic acid in adipocytes demonstrated by suppression of fractalkine, RANTES, and MCP-1 and upregulation of adiponectin. Atherosclerosis 2010;209:89-95.

40 Chai JT, Digby JE, Ruparelia N, Jefferson A, Handa A, Choudhury RP: Nicotinic acid receptor GPR109A is down-regulated in human macrophage-derived foam cells. PLoS One 2013;8:e62934. 


\section{Cellular Physiology Cell Physiol Biochem 2017;42:1420-1430 \begin{tabular}{l|l} 
DOI: 10.1159/000479206 & $\begin{array}{l}\text { O 2017 The Author(s). Published by S. Karger AG, Basel } \\
\text { www.karger.com/cpb }\end{array}$
\end{tabular} \\ Chen et al.: AMP010014A09 Encodes an Analog of GPR109A Receptor in Sus Scrofa}

41 Li G, Shi Y, Huang H, Zhang Y, Wu K, Luo J, Sun Y, Lu J, Benovic JL, Zhou N: Internalization of the human nicotinic acid receptor GPR109A is regulated by G(i), GRK2, and arrestin3. J Biol Chem 2010;285:2260522618.

42 Walters RW, Shukla AK, Kovacs JJ, Violin JD, DeWire SM, Lam CM, Chen JR, Muehlbauer MJ, Whalen EJ, Lefkowitz RJ: beta-Arrestin1 mediates nicotinic acid-induced flushing, but not its antilipolytic effect, in mice. J Clin Invest 2009;119:1312-1321.

43 Li X, Millar JS, Brownell N, Briand F, Rader DJ: Modulation of HDL metabolism by the niacin receptor GPR109A in mouse hepatocytes. Biochem Pharmacol 2010;80:1450-1457.

-44 Lukasova M, Malaval C, Gille A, Kero J, Offermanns S: Nicotinic acid inhibits progression of atherosclerosis in mice through its receptor GPR109A expressed by immune cells. J Clin Invest 2011;121:1163-1173.

45 Kwon WY, Suh GJ, Kim KS, Kwak YH: Niacin attenuates lung inflammation and improves survival during sepsis by downregulating the nuclear factor-kappaB pathway. Crit Care Med 2011;39:328-334.

46 Wanders D, Graff EC, White BD, Judd RL: Niacin increases adiponectin and decreases adipose tissue inflammation in high fat diet-fed mice. PLoS One 2013;8:e71285.

-47 47 Cho KH, Kim HJ, Rodriguez-Iturbe B, Vaziri ND: Niacin ameliorates oxidative stress, inflammation, proteinuria, and hypertension in rats with chronic renal failure. Am J Physiol Renal Physiol 2009;297:F106113.

48 Carlson LA: Nicotinic acid: the broad-spectrum lipid drug. A 50th anniversary review. J Intern Med 2005;258:94-114.

49 Meyers CD, Kamanna VS, Kashyap ML: Niacin therapy in atherosclerosis. Curr Opin Lipidol 2004;15:659665. 